\title{
THE INFLUENCE OF HALAL PRODUCT IMAGE, PRODUCT DESIGN, AND MARKETING STRATEGY ON CONSUMER CONFIDENCE LEVELS IN HALAL COSMETIC PRODUCTS (CASE STUDY ON SAFI)
}

\author{
Alifia Nur Zaida', Khusnul Zulmiati², Nispawatil Isnaini ${ }^{3}$ \\ 1,2,3 Faculty of Economics and Islamic Business, Sunan Kalijaga State Islamic University, \\ Yogyakarta \\ Email: nurzaida005@gmail.com
}

\begin{abstract}
This study want to analyze the effect of the image of halal products, product design, and marketing strategies on the level of consumer confidence in halal cosmetics. This research is more focused on one of the brands of halal cosmetic products, namely Safi, where its products are well known by the wider community. The theoretical framework in this study uses the TOE (Technology, Organization, Environment) framework approach where each independent variable that affects is correlated with this concept. The method used is a quantitative method. Data collection was carried out by distributing questionnaires to respondents, in this case the consumers of Safi halal cosmetic products in Indonesia. This research was conducted using nonprobability techniques. The test of this research is that the authors use SPSS 25.
\end{abstract}

Keywords:Correlation, Zakat Distribution, Gini Index, Income Distribution 


\section{Introduction}

Sustainable Development Goals (SDGs) is a document that becomes a reference in the framework of development and negotiations of countries in the world for the next 15 years until 2030.Since its establishment on September 25, 2015, the SDGs have set 17 global goals with 169 targets to be demanded policies and funding for the next 15 years and are expected to be achieved in 2030 (Wahyuningsih, 2017). These SDGs certainly have an impact on various aspects of life, be it economic, social, political, and so on. The design of the SDGs also has a major influence on the development of the Islamic Economy sector in the world, including in Indonesia. As a country with the largest Muslim population in the world, Indonesia is able to show promising sharia economic development. The development of the Islamic economy in Indonesia is shown in the Global Islamic Finance Report 2017 where Islamic financial assets are ranked 10th globally, reaching USD66 billion. This achievement is expected to increase economic growth in a sustainable manner to realize the SDGs goals (Bank Indonesia, 2018).

The realization of sharia economic development in Indonesia indirectly provides opportunities for the growth of the halal industrial sector. The large number of Muslim population in Indonesia has provided great potential for this country to become a major player in the global halal industry. This potential is mainly supported by increased public awareness of the importance of consuming the halal industry sector. The halal industry market in Indonesia has also shown promising developments. In 2016, the halal food, travel, fashion and pharmaceuticals and halal cosmetics sectors reached around 11\% of the global market. Meanwhile, in 2019 Indonesia was ranked first as a Muslim-friendly tourist destination in the 2019 Global Muslim Travel Index report. The growth of the halal industry in Indonesia has been supported by the halal cosmetics sector which continues to develop(Republika, 2019). According to data from the Ministry of Industry (2018), the demand for halal cosmetics increased significantly in 2018, thus encouraging the growth of the cosmetics industry to increase by $7.35 \%$ in the first quarter. This increase is the influence of the trend of migrating and the lifestyle of Indonesian women to use halal cosmetics (Adriani \& Ma'ruf, 2020).

The current growth of the halal cosmetics sector in Indonesia has indeed provided great opportunities for the development of the market share of the halal industry. But behind this, Indonesia still has to face challenges where some products including cosmetics on the market are still not certified halal. As stated by the Director of LPPOM MUI Lukmanul Hakim, which stated that the number of products that were declared halal in 2012 to 2018 only reached 688,615 products or only $10 \%$ of all products circulating in the market. This is of course a special concern considering that the guarantee of halal products, especially in cosmetic products, is very important to be implemented in Indonesia as the largest Muslim country in the world for the sake of implementing Islamic law.

Inclusion of halal labels on cosmetic products can make it easier for consumers to identify and obtain correct information about the quantity, content, and quality 
related to cosmetic products in circulation. The existence of this halal label also provides benefits for producers, where the inclusion of a halal label on a cosmetic product can build consumer trust and loyalty towards the products they market. Jesslyn and Eko Harry Susanto (2019) in their research have also proven that the halal label can attract public buying interest to use a cosmetic product offered(Jesslyn \& Susanto, 2019). Giving halal labels to cosmetic products can also be a marketing strategy to develop businesses so that they can compete in the global market. As research conducted by Endang Purwanti (2012) which states that marketing strategies have a significant relationship to business development (Purwanti, 2012).

The high level of competition for halal cosmetic products circulating in the global market certainly encourages business actors to strategize neatly so that their products can be more attractive to the wider community. Daniel Reven and Augusty Tae Ferdinand (2017) in their research adopted the concept of product design and from this research, it was found that product design had a positive and significant effect on brand image. This brand image can then influence consumer decisions to buy the products offered as well as being an effort for business actors to compete in the global market(Reven \& Ferdinand, 2017).

Based on the description of the background, this study aims to analyze "The Influence of Halal Product Image, Product Design, and Marketing Strategy on Consumer Confidence Level in Halal Cosmetics Products (Case Study on Safi Products)". The respondents of this study were users of the Safi halal cosmetic product, which is a halal skincare product from Malaysia who has received a halal certificate from the Malaysian Islamic Advancement Office (JAKIM) and the Indonesian Ulema Council (MUI)(Safiindonesia, 2019). Meanwhile, the theory used in this study is the TOE framework theory introduced by Tomatzky and Fleischer in 1990. The variables taken to measure the level of consumer confidence in Safi halal cosmetic products refer to the three contexts in this theory, namely TechnologyOrganization. -Environment.

The theoretical concept of the TOE (Technology-Organization-Environment) framework is generally used in the scope of information technology research. Research in the field of halal cosmetics using the TOE framework theory concept is still rarely done. Therefore, in this study, the researcher adopted three contexts contained in the theory to determine the variables as a measure of the level of consumer confidence in halal cosmetics. The halal product image variable itself is adopted from the context of the TOE framework theory, namely the environment. Meanwhile, the product design variable was adopted from the concept of technology theory and the marketing strategy variable was adopted from the concept of organization theory. The use of these variables aims to explore and test the extent to which the variable image of halal products, product design, and marketing strategies can affect the level of consumer confidence in halal cosmetic products. Researchers assume that the inclusion of halal labels, making attractive product designs, and formulating appropriate strategies can foster consumer confidence in the cosmetic products offered. The existence of consumer trust in halal cosmetic products can also support the realization of the halal value chain and at the same time encourage the 
realization of the SDGs.

\section{Literature Review}

\section{Theory}

Halal products are food products, medicines, cosmetics and other products that do not contain elements or haram items in the manufacturing process and are prohibited from being consumed by Muslims, both with regard to raw materials, additives, other supporting materials including production materials processed through a genetic engineering process irradiation whose processing is carried out in accordance with Islamic law and provides more benefits than madharat (effect) (Nurlaili et al., 2014).

One type of halal product is cosmetics. Cosmetics comes from the word kosmein (Greek) which means "to decorate". Cosmetics have been known to people since time immemorial. In Egypt 3500 BC, various natural materials have been used, both from plants, animals and other natural materials such as clay, mud, charcoal, coal and even fire, water, dew, sand, or sunlight(Tranggono \& Latifah, 2007).

In relation to halal cosmetic products, the design of the product is one thing that determines whether a cosmetic product is attractive or not. (Tahid et al., 2007) define design as the relationship between objects (goods) and certain circumstances or conditions. With the aim of providing satisfaction for users of certain goods or products.

Giving halal labels to cosmetic products can also be a marketing strategy to develop a business. Marketing strategy is a series of goals and objectives, policies and rules that provide direction to the company's marketing efforts from time to time at each level as well as its references and allocations, especially as a company's response to the ever-changing environment and competitive conditions (Assauri, 2015).

Competition by several companies is closely related to competition for the trust of consumers. Kotler and Armstrong (2013) state that 'Belief is a description of a person's thoughts about something. Consumer confidence has characteristics (indicators), namely: (1) Knowledge of brands; (2) Personal and community views; (3) Brand honesty; (4) Brand strength or advantage; and (5) personal experience (Kotler dan Amstrong, 2013).

A model regarding the relationship between technology, organization and the environment was introduced by Tomatzky and Fleischer (1990). The TechnologyOrganization-Environment (TOE) framework is a model of technology acceptance at the enterprise level, which examines three major influences on the potential for technology acceptance or technological innovation adoption: technology, organization, and the environment(Setiobudi \& Wiradinata, 2018). 


\section{Framework}

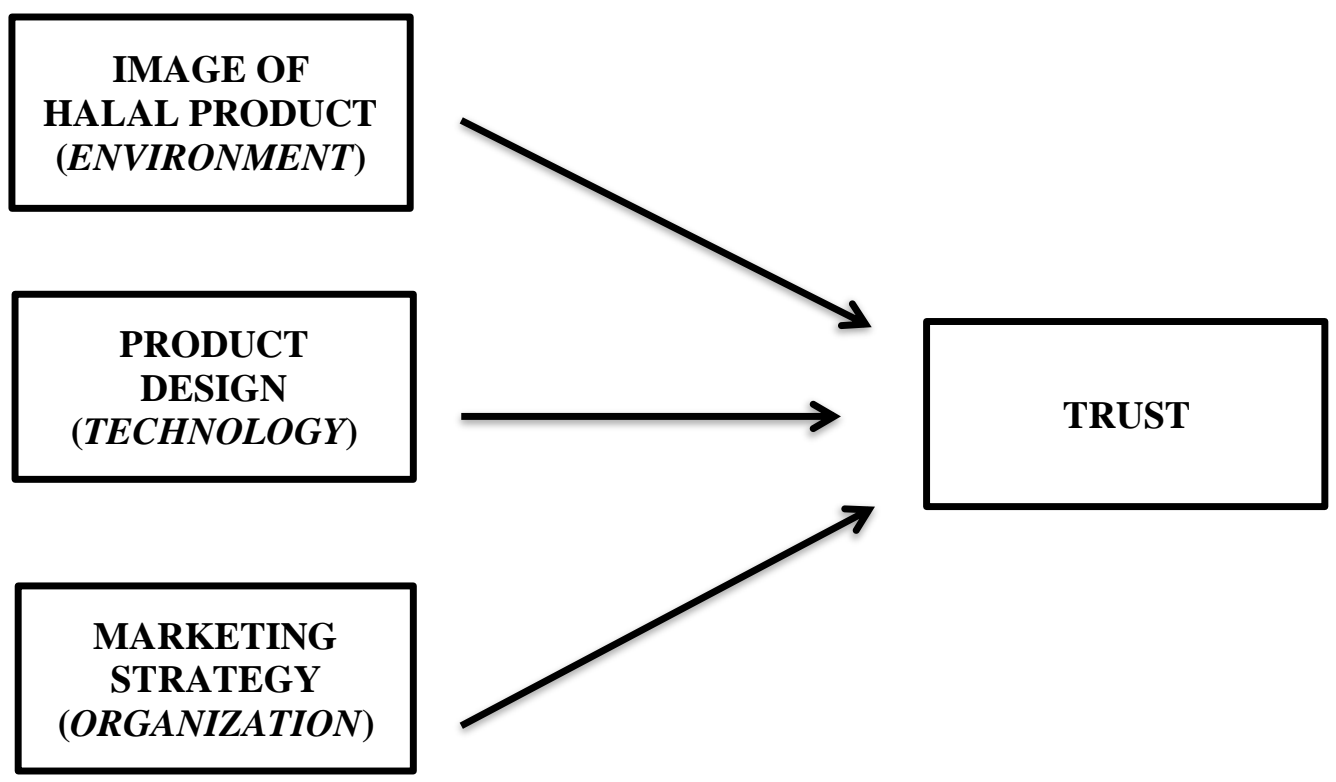

\section{Hypothesis Development}

1. The Influence of Image of Halal Products on Consumer Confidence Level

According to Law Number 33 of 2014 concerning Halal Product Guarantee, it is stated that halal products are products that have been declared halal, based on the provisions of Islamic law. Halal in general is not only limited to the goods but also related to how to get it which is done in a halal manner(Iwan Zainul Fuad, 2010). If a product is in the form of food, beverage, medicine or cosmetics, it has a halal label, of course, it will attract more public interest in these products. As research conducted by Jesslyn and Eko Harry Susanto (2018) shows that a halal label can attract people's buying interest to use a cosmetic product that is offered. Researchers also have a rationalization for this relationship, where the image of halal products can attract public interest as well as foster a level of consumer confidence in the products offered (Jesslyn \& Susanto, 2019). Therefore, researchers assume that the image of halal products affects the level of consumer confidence.

H1: The image of a halal product has a significant positive effect on the level consumer confidence in Safi halal cosmetic products.

2. Effect of Product Design on Consumer Confidence Level

Product design is a product feature that affects the appearance and value of use for consumers, and the appearance of the product becomes a differentiator for a product from one brand to another. Daniel Reven and Augusty Tae Ferdinand (2017) in their research adopted the concept of product design and from this research, it was found that product design had a positive 
and significant effect on brand image. This brand image can then influence consumer decisions to buy the products offered as well as being an effort for business actors to compete in the global market(Reven \& Ferdinand, 2017). Referring to previous research, researchers assume that product design can ultimately foster a level of consumer confidence in a product offered through the brand image it builds. Therefore, the researcher formulated the following hypothesis:

$\mathrm{H} 2$ : The product design has a significant positive effect on levels consumer confidence in Safi halal cosmetic products.

3. The Effect of Marketing Strategy on Consumer Confidence Level

Marketing strategy is a plan that is owned by a company as a guideline for marketing activities to achieve the goals set by the company(Swasta, 1999). Marketing strategy is a statement (either implicitly or explicitly) about how a brand or product line achieves its objectives. Based on research conducted by Endang Purwanti (2012), this marketing strategy has a significant relationship with business development (Purwanti, 2012). Referring to this research, researchers assume that marketing strategies will be able to realize business development if there is trust from consumers in the business that is being carried out. Therefore, the researcher formulated a hypothesis that marketing strategy affects the level of consumer confidence.

H3: Marketing strategy has a significant positive effect on levels consumer confidence in Safi halal cosmetic products.

\section{Research Methods}

This research uses a quantitative approach, which is an approach using quantitative data or types of data that can be quantified and then processed with statistics (Yusuf, 2017). The respondents involved in this study were 61 people. In collecting the questionnaire, the researcher managed to collect as many as 121 respondents. After going through the filtering process, the data that met the criteria were 61 respondents. Sampling in this study used a non-probability sampling technique. The nonprobability sampling technique is a sampling technique that is based on each member of the population not having the same opportunity(Priyono, 2016). The data collection method in this study was conducted using a questionnaire technique. A questionnaire is a series of questions related to a certain topic given to a group of individuals with the intention of obtaining data (Yusuf, 2017). The questionnaire was distributed to a number of people who use Safi products with several restrictions, including Indonesian citizens (WNI) who are female, ranging in age from 20-29 years with an income of above IDR 3,000,000 and a minimum usage of 6 months. The questionnaire consists of several questions regarding the image of halal products, product design and marketing strategies for consumer trust, which are presented in easy to understand language. 


\section{Data Analysis Method}

This study used a regression method with a cross section approach. This study uses the Ordinary Least Square (OLS) method. The essence of the OLS method is to estimate a regression line by minimizing the number of squares of the error for each observation on that line. In analyzing the relationship between these variables, data processing is carried out with the help of the SPSS 25 program. Model $Y=a+\beta 1$ Halal Product Image $+\beta 2$ Product Design $+\beta 3$ Marketing Strategy + e.

\section{Validity Test}

The data validity test is used to measure whether a questionnaire is valid or not(Ghozali, 2006). Validity testing is done by using the Pearson Correlation Product Moment correlation technique, which is how to correlate the scores of each variable with the total score. The measuring instrument can be said to be valid if rcount $>$ rtable otherwise if rcount <rtabel then the measuring instrument used is invalid.

\section{Reliability Test}

Reliability test is used to measure a questionnaire, and is used to measure the answers of respondents to the statements in the questionnaire. This can be seen when the answers from respondents are consistent, it can be said that the questionnaire is reliable. According to Ghozali (2006) the reliability test can be seen if the Cornbach's Alpha value is $>0.60$ then the variable can be said to be reliable(Ghozali, 2006).

\section{Result and Discussions}

\section{Validity Test}

The data validity test is used to measure whether a questionnaire is valid or not (Ghozali, 2006). The measuring instrument can be said to be valid if rcount> rtable otherwise if rcount $<$ rtabel then the measuring instrument used is invalid.

Table 1 Validity Test

\begin{tabular}{|c|c|c|c|c|c|c|c|}
\hline Variable & R. Count & R. Table & Decision & Variable & R. Count & R. Table & Decision \\
\hline X1_1 & 0.703 & \multirow{5}{*}{0.2521} & \multirow{5}{*}{ VALID } & X2_1 & 0.774 & \multirow{5}{*}{0.2521} & \multirow{5}{*}{ VALID } \\
\hline X1_2 & 0.701 & & & $X 2 \_2$ & 0.772 & & \\
\hline X1-3 & 0.829 & & & X2_3 & 0.796 & & \\
\hline X1_4 & 0.831 & & & $X 2 \_4$ & 0.842 & & \\
\hline X1_5 & 0.777 & & & X2_5 & 0.808 & & \\
\hline
\end{tabular}

\begin{tabular}{|c|c|c|c|c|c|l|l|}
\hline Variable & $\begin{array}{c}\text { R. } \\
\text { Count }\end{array}$ & R. Table & Decision & Variable & R. Count & R. Table & Decision \\
\hline X3_1 & 0.683 & \multirow{2}{*}{0.2521} & VALID & Y1 & 0.885 & \multirow{2}{*}{0.2521} & VALID \\
\cline { 1 - 5 } X3_2 & 0.824 & & & $Y 2$ & 0.761 & & \\
\hline
\end{tabular}




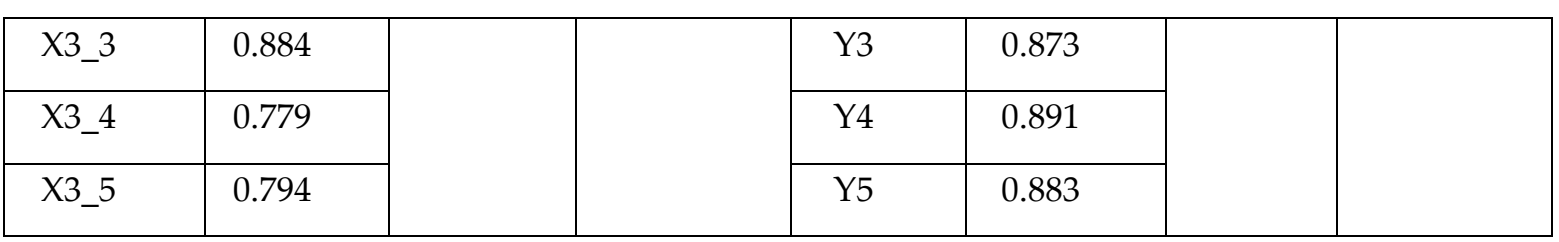

Based on the results of questionnaire data processing from 61 respondents, from the twenty questions it was found that the rcount value was greater than the rtable value. Thus, it can be concluded that the instrument or question items of each variable have a significant correlation to the total score and are declared valid.

\section{Reliability Test}

Reliability test is used to measure a questionnaire and is used to measure the answers of respondents to the statements in the questionnaire. According to Ghozali (2006) the reliability test can be seen if the Cornbach's Alpha value is $>0.60$ then the variable can be said to be reliable(Ghozali, 2006).

Table 2 Reliability Test

\begin{tabular}{|c|c|c|}
\hline Variable & Cronbach's Alpha & Information \\
\hline mage of Halal Product & 0.826 & \multirow{2}{*}{ Reliable } \\
\hline Product Design & 0.856 & \\
\cline { 1 - 2 } Marketing Strategy & 0.853 & \\
\hline Trust & 0.908 & \\
\hline
\end{tabular}

Based on the results of the reliability test, data was obtained which stated that of the twenty question items given to 61 respondents, both variables $\mathrm{X} 1, \mathrm{X} 2, \mathrm{X} 3$, and variable $Y$ had a Cronbach's Alpha value greater than 0.60 , which means that all question items were declared reliable.

\section{Classic Assumption Test}

1. Normality Test

The normality test aims to determine whether in the regression model, confounding or residual variables have a normal distribution or not (Widarjono, 2007). The normality test in this study used the Saphiro Wilks test. If the prob Z value $>0.05$, the residual value is normally distributed. 
Table 3 Normality Test

One-Sample Kolmogorov-Smirnov Test

\begin{tabular}{|ll|r|}
\hline & & $\begin{array}{r}\text { Unstandardiz } \\
\text { ed Residual }\end{array}$ \\
\hline N & 61 \\
Normal Parameters $a, b$ & Mean &, 0000000 \\
Most Extreme & Std. Deviation & 2,52315123 \\
Differences & Absolute &, 106 \\
& Positive &, 067 \\
Kolmogorov-Smirnov Z & Negative &,- 106 \\
Asymp. Sig. (2-tailed) & &, 829 \\
\hline
\end{tabular}

Based on the results of the normality test output using the Kolmogrov Smirnov Test method, it was obtained a value of 0.829 and an Asymp Sig of 0.497 greater than 0.05. So it can be concluded that the data is normally distributed and shows that the variable image of halal products, product design, and marketing strategies can be investigated on the level of public trust in halal cosmetic products.

\section{Multicollinearity Test}

Multicollinearity test aims to test the correlation between independent variables (independent) in the regression model. In the multicollinearity test the methods used are the tolerance and VIF (Variant Inflation Factor) methods. If the Varian Inflation Factor (VIF) value is $\leq 10$ and the tolerance value is greater than 0.10 , it can be said to be free from multicollinearity.

Table 4 Multicollinearity Test

Coefficients ${ }^{a}$

\begin{tabular}{|ll|r|r|}
\hline \multirow{2}{*}{ Model } & \multicolumn{2}{|c|}{ Collinearity Statistics } \\
\cline { 3 - 4 } & & Tolerance & \multicolumn{1}{c|}{ VIF } \\
\hline 1 & TOT_X1 &, 770 & 1,299 \\
& TOT_X2 &, 623 & 1,605 \\
& TOT_X3 &, 631 & 1,586 \\
\hline
\end{tabular}

Based on the output table above, it is known that the Tolerance Variable values $\mathrm{X} 1, \mathrm{X} 2$, and $\mathrm{X} 3$ are greater than 0.10 , namely $0.770 ; 0.623 ; 0.631$ and the VIF value is smaller than 10 , namely $1.299 ; 1,605 ; 1,586$. So that the independent variable $(X)$ in the study is declared free from multicollinearity, which means that there is no correlation between the independent variables $(\mathrm{X})$.

\section{Heteroscedasticity}

The heteroscedasticity test aims to test whether in the regression there is an inequality of variance from the residuals of one observation to another. To see the heteroscedasticity, the Breusch-Pagan method was used and the residual plot was observed. If the value of Prob> chi2 is more than 0.05, there is no heteroscedesity (homocedesity) and if no point in the plot graph is too far away, it means that it has 
homocedesity. Following are the results of the heteroscedasticity test by looking at the plot graph:

Figure 1 Heteroscedasticity Test

Dependent Variable: TOT_Y

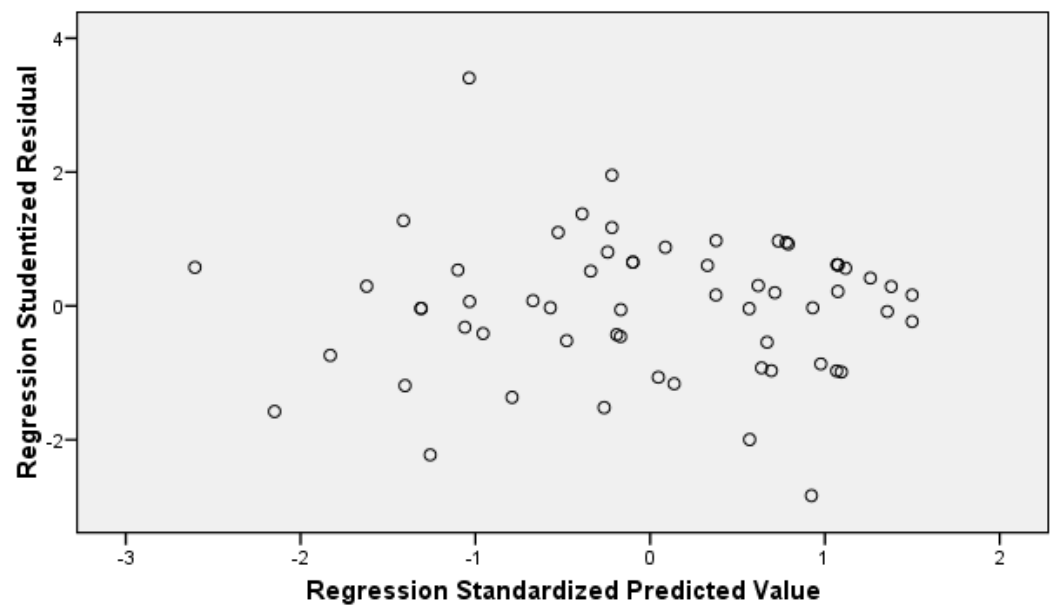

From the graph, we can see that the data spreads randomly above and below zero and does not form a specific pattern. Thus, it can be concluded that the regression model is free from heteroscedasticity.

\section{Hypothesis Testing}

\section{F Test}

The F test is conducted to test all regression coefficients simultaneously. The F-test is conducted to test the null hypothesis that all independent variables have no effect on the dependent variable. The F test can be seen from prob> F, if the value is less than 0.05 then there is an influence between the dependent and independent variables simultaneously.

Table 5 F Test Result

\begin{tabular}{|c|c|c|c|c|c|c|}
\hline \multicolumn{7}{|c|}{ ANOVA $^{b}$} \\
\hline \multicolumn{2}{|c|}{ Model } & $\begin{array}{l}\text { Sum of } \\
\text { Squares }\end{array}$ & df & Mean Square & $\mathrm{F}$ & Sig. \\
\hline \multirow[t]{3}{*}{1} & Regression & 426,777 & 3 & 142,259 & 21,228 &, $000^{9}$ \\
\hline & Residual & 381,978 & 57 & 6,701 & & \\
\hline & Total & 808,754 & 60 & & & \\
\hline
\end{tabular}

a. Predictors: (Constant), TOT_X3, TOT_X1, TOT_X2

b. Dependent Variable: TOT_Y

Based on the table above, the calculated $\mathrm{F}$ value is 21.228 , while the $\mathrm{F}$ table is 2.77 . This means that $\mathrm{F}$ count is greater than $\mathrm{F}$ table (21.228> 2.77). Based on the way of making simultaneous test decisions in regression analysis, it can be concluded that the variables of halal product image, product design, and marketing strategies have an effect on the trust variable.

\section{T Test}

The $t$ test is used to partially test the effect of the independent variable on the dependent variable. Suppose to determine whether to reject or not reject a null hypothesis (H0). If the 
value of $\mathrm{p}>|\mathrm{t}|$ less than 0.05 , there is a relationship between the dependent and independent variables partially.

Table 6 T Test Result

\begin{tabular}{|c|c|c|c|c|c|c|}
\hline \multirow{2}{*}{\multicolumn{2}{|c|}{ Model }} & \multicolumn{2}{|c|}{$\begin{array}{c}\text { Unstandardized } \\
\text { Coefficients }\end{array}$} & \multirow{2}{*}{$\begin{array}{c}\text { Standardized } \\
\text { Coefficients } \\
\text { Beta }\end{array}$} & \multirow[b]{2}{*}{$t$} & \multirow[b]{2}{*}{ Sig. } \\
\hline & & $\mathrm{B}$ & Std. Error & & & \\
\hline \multirow[t]{4}{*}{1} & (Constant) & $-2,418$ & 2,939 & &,- 823 & .414 \\
\hline & TOT_X1 &, 378 & , 125 &, 313 & 3,017 &, 004 \\
\hline & TOT_X2 &, 319 & 128 & ,288 & 2,497 &, 015 \\
\hline & TOT_X3 &, 384 & , 146 &, 300 & 2,621 &, 011 \\
\hline
\end{tabular}

Based on this table, the following conclusions can be drawn:

a. In the halal product image variable, the $t$ value is 3.017 and the sig value is 0.004 which means it is smaller than the 0.05 probability. So, the variable image of halal products has a significant effect on the variable level of consumer confidence in halal cosmetic products or the hypothesis is accepted.

b. In the product design variable, the $t$ value is 2.497 and the sig value is 0.015 , which means it is smaller than the probability of 0.05 . So, the product design variable has a significant effect on the variable level of consumer confidence in halal cosmetic products or the hypothesis is accepted.

c. In the marketing strategy variable, the t value is 2.621 and the sig value is 0.011 , which means that it is smaller than the probability of 0.05 . So, the marketing strategy variable has a significant effect on the variable level of consumer confidence in halal cosmetic products or the hypothesis is accepted.

\section{3. $\mathrm{R}^{2}$ Test}

Basically R2 measures the proportion of variations in the dependent variable that can be explained by various variations in the independent variable. The value of R2 ranges from $0<\mathrm{R} 2<1$. The value of $\mathrm{R} 2$ which is closer to number one indicates that the independent variables are increasingly able to explain changes in the dependent variable well.

Table $7 \mathrm{R}^{2}$ Test Result

\begin{tabular}{|l|r|r|r|r|}
\hline Model & \multicolumn{1}{|c|}{ R } & R Square & $\begin{array}{c}\text { Adjusted } \\
\text { R Square }\end{array}$ & $\begin{array}{r}\text { Std. Error of } \\
\text { the Estimate }\end{array}$ \\
\hline 1 &, $726^{\mathrm{a}}$ &, 528 &, 503 & 2,58870 \\
\hline
\end{tabular}

Based on the table above, the value of $\mathrm{R}$ Square is 0.528 or $52.8 \%$. The variable level of consumer confidence can be explained by the variable image of halal products, product design, and marketing strategies. While the remaining $47.2 \%(100 \%-52.8 \%)$ is influenced by variables other than those used in this study. While the double coefficient $(R)=0.726$ indicates that the independent variable $(X)$ has a strong influence on the dependent variable $(\mathrm{Y})$. 


\section{Analysis}

Based on the results of the partial hypothesis test that has been carried out by the researcher, the results show that:

1. Image of Halal Products on Consumer Confidence Level

The $t$-test results show the variable image of halal products, the $t$ value is 3.017 and the sig value is 0.004 which means it is smaller than the probability of 0.05 . This shows that the effect of the image of halal products on the level of consumer confidence has positive results, meaning that the existence of a halal label on cosmetic products will give more image to these products to grow the level of consumer confidence in the cosmetic products offered.

This research is in line with the research conducted by Jesslyn and Eko Harry Susanto (2019) who show that the halal label can attract public buying interest to use a cosmetic product offered (Jesslyn \& Susanto, 2019). The existence of high public buying interest indicates that the level of consumer confidence in a cosmetic product is also high. Therefore, H1 which reads "The image of halal products has a significant positive effect on the level of consumer confidence in Safi halal cosmetic products" can be accepted.

\section{Product Design on Consumer Confidence Level}

The t-test results show that for the product design variable, the $t$ value is 2.497 and the sig value is 0.015 which means it is smaller than the 0.05 probability. This shows that the effect of product design on the level of consumer confidence has positive results, meaning that the more attractive the design of cosmetic products is, the higher the level of consumer confidence in the cosmetic products offered.

This research is in line with the research conducted by Daniel Reven and Augusty Tae Ferdinand (2017) who show that product design has a positive and significant effect on brand image. It is through this brand image that the level of consumer confidence in a cosmetic product can be built (Reven \& Ferdinand, 2017). Therefore, the $\mathrm{H} 2$ which reads "Product design has a significant positive effect on the level of consumer confidence in Safi halal cosmetic products" is acceptable.

\section{Marketing Strategy on Consumer Confidence Level}

The t-test results show that for the marketing strategy variable, the $t$ value is 2.621 and the sig value is 0.011 which means it is smaller than the 0.05 probability. This shows that the effect of marketing strategies on the level of consumer confidence has positive results, meaning that the right marketing strategy for a cosmetic product will be able to foster a level of consumer confidence in the cosmetic products offered.

This research is in line with research conducted by Endang Purwanti (2012) which shows that this marketing strategy has a significant relationship with business development. The marketing strategy will be able to develop a business about the cosmetics industry if there is trust from consumers in the cosmetic products offered (Purwanti, 2012). Therefore, H3 which reads "The marketing strategy has a significant positive effect on the level of consumer confidence in Safi halal cosmetic products" acceptable. 


\section{Conclusion}

The results showed that all the hypotheses formulated were acceptable. Based on the results of the research as described in the previous chapter, it can be concluded that the image of halal products, product design, and marketing strategies has a significant relationship to the level of consumer confidence in Safi halal cosmetic products. Therefore, to foster a level of consumer confidence in the cosmetic products offered, it is necessary to pay attention to several factors that influence it, namely the inclusion of halal labels, making attractive product designs, and formulating appropriate marketing strategies. In this study, Safi halal cosmetic products are considered to have fulfilled these three factors so that they can grow the level of consumer confidence in their halal cosmetic products.

\section{References}

Adriani, L., \& Ma'ruf. (2020). Pengaruh Islamic Religiosity dan Halal Knowledge terhadap Purchase Intention Kosmetik Halal Dimediasi oleh Attitude terhadap Produk Halal di Indonesia. AL-MUZARA'AH.

https://doi.org/10.29244/jam.8.1.57-72

Assauri, S. (2015). Manajemen Pemasaran. In PT RajaGrafindo Persada, Jakarta.

Bank Indonesia. (2018). Pengembangan Industri Halal Dukung Pertumbuhan Ekonomi

Nasional. Bank Indonesia. https://www.bi.go.id/id/publikasi/ruang-media/newsrelease/Pages/Pengembangan-Industri-Halal-Dukung-Pertumbuhan-EkonomiNasional.aspx

Ghozali, I. (2006). Ghozali, Imam. 2006. Aplikasi Analisis Multivariate dengan Program SPSS. Semarang: Badan Penerbit UNDIP. In Analisis Multivariate dengan Program SPSS.

Iwan Zainul Fuad, S. (2010). KESADARAN HUKUM PENGUSAHA KECIL DI

BIDANG PANGAN DALAM KEMASAN DI KOTA SEMARANG TERHADAP REGULASI SERTIFIKASI PRODUK HALAL. بيياريهاى داخلى.

Jesslyn, J., \& Susanto, E. H. (2019). Analisis Penggunaan Label Halal pada Produk

Kecantikan Brand Safi dalam Menarik Minat Beli Masyarakat. Prologia.

https://doi.org/10.24912/pr.v2i2.3716

Kotler dan Amstrong. (2013). Prinsip-Prinsip Pemasaran Jilid I. In Erlangga.

Nurlaili, Ekawati, E., \& Eliza, A. (2014). Program Sosialisasi Label Halal/Sertifikat Halal

Pada Produk Makanan Siap Saji. LP2M Raden Intan Lampung.

Priyono. (2016). Metode Penelitian Kuantitatif. Zifatma Publishing.

Purwanti, E. (2012). Pengaruh Karakteristik Wirausaha, Modal Usaha, Strategi

Pemasaran Terhadap Perkembangan Umkm Di Desa Dayaan Dan Kalilondo

Salatiga. Among Makarti.

Republika. (2019). Dorong Ekonomi Syariah Jadi Sumber Pertumbuhan Ekonomi Baru.

Republka. https://republika.co.id/amp/q07zhc423

Reven, D., \& Ferdinand, A. T. (2017). Analisis Pengaruh Desain Produk, Kualitas

Produk, Harga Kompetitif, dan Citra Merek Terhadap Keputusan Pembelian. 
Analisis Pengaruh Desain Produk Kualitas P Roduk, 6(3), 1-13.

Safiindonesia. (2019). Safi. https://www.safiindonesia.com/

Setiobudi, A., \& Wiradinata, T. (2018). INTENSI UKM DALAM ADOPSI

FINANCIAL TECHNOLOGY DI JAWA TIMUR. National Conference of Creative Industry. https://doi.org/10.30813/ncci.v0i0.1233

Swasta, B. (1999). Azas-Azas Marketing. Yogyakarta: Liberti.

Tahid, S., Nurcahyanie, Y. D., \& Yulia. (2007). Konsep Teknologi dalam Produk Industri. Kencana.

Tranggono, R. I., \& Latifah, F. (2007). Buku Pegangan Ilmu Pengetahuan Kosmetik. In Buku Pegangan Ilmu Pengetahuan Kosmetik.

Wahyuningsih. (2017). Millenium Develompent Goals ( Mdgs ) Dan Sustainable Development Goals ( Sdgs ) Dalam. Bisnis Dan Manajemen.

Yusuf, A. M. (2017). Metodologi Penelitian Kuantitatif, Kualitatif \& Penelitian Gabungan. In BMC Public Health. 